\title{
Quincy Wright's study of the mandates system
}

\author{
HAROLD K. JACOBSON
}

Department of Political Science, University of Michigan ${ }^{1}$

Few books that were published in the 1930 s in the field of international relations still deserve serious attention from scholars in the 1970s. As the world changes, so to a certain extent does the subject matter of international relations. Moreover, the importance and urgency of the real-world problems falling within the domain of that discipline prompt international relations scholars to concentrate on immediate and often ephemeral issues. Finally, this field of inquiry was just beginning in 1930; in the last four decades, concepts and techniques of analysis in the field have become increasingly sophisticated. Thus one would hardly expect a 1930 book to be of more than antiquarian interest.

However, Quincy Wright's Mandates Under the League of Nations (1930) can still be read with profit even by those who have little concern for documenting the historical growth of the discipline and are anxious to get on with its present development. It is true that with the passing of colonialism the mandates system-in its more modern guise, the UN trusteeship system-has largely become a matter of the past. Nevertheless, the system was an important feature of both the League of Nations and the United Nations, and it is one about which those working in the field of international relations should know some-

\footnotetext{
${ }^{1}$ The author is presently on leave at the Carnegie Endowment for International Peace, European Center (Geneva) where he is Visiting Research Scholar, 1970-71.
}

thing. Though many books have been written about mandates and trusteeship since 1930, none of them approaches Wright's early study in breadth of conception or depth of analysis and understanding. If one had time to read only one book on mandates and trusteeship systems, it would be Mandates Under the League of Nations. But the study has interest far beyond this. A detailed study of the interaction between the policies of states and an international organization, it is full of profound insights. As one of the great books dealing with international organization, it can still serve as a model for scholarship in the field. Mainly for this reason, it continues to merit reading.

Wright's study deserves emulation first in its broad and comprehensive coverage of the subject and in the concept of international organization implicit in this treatment. $\mathrm{He}$ asked why and how the League of Nations became involved in overseeing colonial administration through the mandates system, how it was performing this task, and with what effects. Putting it in the language of systems analysis, he was concerned with inputs, conversion processes, and outputs. Pursuit of this first topic led him to a detailed examination of the origins of the mandates system and the negotiations for its creation. In examining the second question he conducted a close analysis of the behavior of the League Secretariat, the Permanent Mandates Commission, the Council, and the Assembly. In this analysis he was acutely sensitive to the many and frequently 
subtle relationships between individual actions and state policies. He recognized both that the behavior of individuals acting in their own capacity was conditioned by their background and associations and thus by their nationality, and that governmental representatives were more than merely spokesmen and had some ability to determine their actions. Finally, he asked what direct and indirect effects the League's supervisory activities had on the mandated territories.

Wright well understood that international organizations were not fully autonomous political systems and that they could be viewed realistically only in conjunction with the international system of which they were an integral part. Despite his central thesis that the unique contribution of the mandates system was in providing machinery for continuous and systematic international supervision of colonial administration (pp. 23, 64, 585) he had no illusions that this machinery was completely divorced from the policies of states or that it could become so divorced in any forseeable future. He was also well aware that states alone had the capacity to carry out any recommendations that the international machinery might make. Finally, he knew that the effectiveness of the international machinery had to be measured by its impact on the policies of states.

The concept of states employed throughout the book is as sophisticated as that of international organization; it also deserves emulation. Wright saw states, not as identical or as monolithic units, but as complicated social groups, the actions of which depended on a variety of factors including the attitudes and power of their leadership, the views of the informed public, and mass opinion. These factors in turn were shaped by a state's geographic, economic, and military position, as well as its culture and traditions. Consequently he did not expect that states would behave uniformly, nor did he expect unanim- ity within states about the foreign policies that they should follow. That there are differences among states is an obvious fact which no scholar in the field of international organization could ignore; many, however, have ignored differences within states. Wright, in contrast, expected that for a state to decide on a course of action would usually involve somehow settling differences among conflicting points of view. He saw that international organizations would be affected by the way differences among and within states would be decided, and he clearly demonstrated that the mandates system was a compromise among those groups which thought that the status of the non-European territories yielded by Germany and Turkey during the first World War should be settled (a) by giving them independence, (b) by fully internationalizing them, (c) by allowing them to be annexed by the victorious powers, or (d) by restoring them to their former owners (pp. 24-63). He also saw that international organizations could affect such compromises as well as be affected by them. For example, he argued that the Permanent Mandates Commission contributed to making the Syrian demand for more self-government "partially effective" (p. 566), presumably by providing an instrument for articulating these demands and indirectly strengthening the hand of those in France who favored granting concessions.

The search for theoretical understanding in Mandates Under the League of Nations is also worthy of imitation. This search is most evident in chapter VII, entitled "The Supervision of Mandatory Administration" (pp. 190-218), in which Wright asked how the League's machinery worked and what it depended on for its effectiveness. He considered domestic analogies and concluded that "the League's ordinary activity in relation to mandates clearly has a closer resemblance to administrative than to either legislative or judicial methods" (p. 195). In his view the 
League would usually have to rely on giving advice to the colonial powers, and he felt that this advice would be more effective if it were anticipatory rather than remedial. He saw the creation of standards as a way of giving anticipatory advice. Positing on underlying rationality in bureaucracies, he argued that if the League gave sound and valuable advice it would be followed. He acknowledged that the system's effectiveness depended to a considerable extent on the "good faith" of the states administering the mandates, but also stressed the importance of the sanction of publicity.

Nations do not like to endure the contempt or disgust of the world, and the certainty that any malfeasance in the mandated areas will be widely known is a deterrent which will become steadily more important as world-opinion becomes more organized through the League [p. 216].

Although Wright does not make this point, the notion that states are composed of groups with divergent views is clearly essential to his emphasis on publicity as a sanction, for an international organization could only achieve objectives through publicity if there were some support for these objectives within the state involved: the function of the publicity would be to mobilize latent support, or, if such support were already activated, to nourish and strengthen it.

Finally, Mandates Under the League of Nations can serve as a model for studies of international organization because of Wright's attempts to operationalize some of the concepts he used and to measure the issues he was examining precisely and quantitatively. In trying to ascertain to what extent the mandates system was supported, he used allocations of the League's budget as a rough indication of the importance that states attached to the system (pp. 66-67). He sought further evidence of support in the expressed opinion of scholars, officials, and political leaders in the mandated territories, in the administering states, and in other states (pp. 64-98). He gathered material for this and other sections of the book through field research in the mandated territories and at League headquarters in Geneva. Although this effort to study attitudes appears primitive in comparison with the sophisticated techniques used in modern opinion analysis, it is still impressive in its global coverage and in its attempt to probe all levels of opinion: elite, informed public, and mass. Later in the book Wright attempted to measure the impact of the mandates system by comparing expenditures and achievements in the mandated territories with those in roughly comparable ordinary colonial dependencies (pp. 541-81). The results are so tantalizing as to make one deeply regretful that no subsequent scholars have followed this lead. We can return shortly to consider why scholars have not done this and why there are certain lacunae in the book itself between the data that were presented and the accompanying policy conclusions and recommendations. Here it should be noted that, while Wright sought to use quantitative data, in his interpretations he was always sensitive to the limitations of statistical analyses. He fully recognized the possible inaccuracies in the data, the difficulty of linking available statistics to some of the concepts that he was trying to measure, and the complicated problems of assessing causation. This sensitivity too is worthy of being copied.

If Wright's book had been published in 1970 rather than forty years earlier, many reviewers might well have asked for more explicit conceptualization and formulation and testing of hypotheses. Considering the general mode of scholarship in the field when it was published, that it went as far as it did is much more striking than its shortcomings in these respects. Within its own frame of reference, however, the book can be criticized. There is throughout a somewhat uncritical acceptance of Western and particularly American policy positions. This is especially ob- 
vious in his discussion of the application of the open door principle to the mandated territories. It may well have been the case, as Wright argued throughout the book, that the application of the open door principle to the mandated territories had beneficial effects for the inhabitants of these territories by widening their opportunities for commerce. Yet it seems something of an understatement to pass off the economic self-interest of nonadministering states in pressing for the application of the principle with such sentences as, "Third states may incidentally benefit from this" (p. 261). Indeed, elsewhere, Wright shows how as a consequence of United States pressure for application of the open door principle, American oil interests "were permitted to acquire 25 percent of the shares of the Turkish Petroleum Company, which had obtained from Iraq an exclusive concession for oil development in the Bagdad and Mosul villayets ..." (pp. 60-61). His Western bias is also evident in his general and undiscriminating characterization of the mandated territories as "backward areas," and his acceptance of the notion that for such areas the alternative "of self-determination by inexperienced or incompetent natives would be impracticable" (p. 584). At the very least such generalizations ignored the distinctions written into Article 23 of the Covenant of the League of Nations and did considerable injustice to the advanced status of the territories in the Middle East that formerly belonged to the Turkish Empire, namely: Iraq, Palestine (and Transjordan), Syra, and Lebanon. Wright reported the unpopularity of the mandates system in these territories (pp. 92-93), except among the Jews in Palestine, but virtually ignored these critical views in his evaluation of the system. Thus the overall framework of his evaluation clearly stemmed from a Western weltanschauung.

Another criticism rests on evidence within the book itself. The lengthy effort to prove that, in the event of a breach of the mandate by the administering state, the League Council had the right to transfer the mandate (culminating on pp. 522-33) seems somewhat bizarre in view of Wright's detailed recounting of the way in which the mandates were assigned. It also goes against his own conclusion, mentioned above, that the effectiveness of the system rested on the ability of the League to give reasoned advice, on good faith on the part of the administering states, and on the sanction of publicity.

The book also contains other apparent gaps in reasoning. Wright's detailed examination of developments in the mandated territories and comparisons with developments elsewhere leaves a reader with quite mixed feelings about the benefits of mandate status. Yet he concluded that the principal function of the mandates system was and should be to set "examples for the administration of backward areas everywhere" (p. 588). Quite apart from the question of whether or not the mandated territories could serve as good examples, the issue of the administering states applying the lessons that they might gain from the examples was hardly broached in the book. In retrospect the main function of the mandates and trusteeship systems seems to have been that they provided one more instrument for nationalist leaders to use in their struggle for independence. The inhabitants of mandated and trust territories may have fared better in some respects than colonial subjects without this special status, but they probably fared worse in other respects, particularly economic development. Wright could not have been expected to foresee developments then far in the future, but he could have been asked to pay greater attention to his own data. And had he been willing to push his analysis to its logical conclusions he should have been more skeptical than he was about the ability of a body based in Geneva-the Permanent Mandates Commission-to provide effective anticipatory advice for distant colonial administrators.

There may be an underlying explanation for 
Wright's seeming unwillingness to follow his analysis to its logical conclusions. Quincy Wright was a pioneer not only in scholarship in the field of international relations, but also in the creation of world order. His conviction that international institutions were strategically vital for creating world order is evident throughout the pages of Mandates Under the League of Nations. Because he was personally committed to increasing the authority of international institutions, his conclusions almost inevitably pointed in this direction. Many students of international organization have shared his commitment, as demonstrated by the fact that so little has been done to follow some of the more critical leads he gave. In a passage that reveals another aspect of his personal beliefs, Wright argued that the mandates system offered an opportunity for "international science to guide national policy in handling problems as they arise ..." (p. 586). Thus his commitment to the develop- ment of scholarship and to the development of international institutions had a basic unity, dominated by the latter.

To point out that Quincy Wright's personal values may have biased his study carries the implicit argument that contemporary scholars should take a more neutral approach toward international institutions. But ironically, this can be taken as a tribute to him rather than as a criticism. International institutions are now well established and can easily stand critical analysis and hopefully will profit from it. Were it not for this accomplishment, attributable in some part to Wright and others like him, present day scholars might well feel that they could hardly afford dispassionate analysis.

\section{REFERENCE}

Wright, Quincy. Mandates Under the League of Nations. Chicago: University of Chicago Press, 1930. 